OECDpublishing

WILL IT STAY OR WILL IT GO?

ANALYSING DEVELOPMENTS IN

TELEWORK DURING COVID-19 USING

ONLINE JOB POSTINGS DATA

PAWEL ADRJAN

GABRIELE CIMINELLI

ALEXANDRE JUDES

MICHAEL KOELLE

CYRILLE SCHWELLNUS

TARA SINCLAIR

OECD PRODUCTIVITY

WORKING PAPERS

December 2021 No. 30 


\section{OECD PRODUCTIVITY WORKING PAPERS}

The OECD Productivity Working Papers are associated with the Global Forum on Productivity that provides a forum for mutual exchange of information and fosters international co-operation between public bodies with responsibility for promoting productivity-enhancing policies, including in undertaking joint policy analysis. It offers a platform for exchanging views, experiences and information, institutional and governance arrangements and government structures, with a view towards developing better policies. The Forum extends existing work in the OECD through a well-prioritised and coherent stream of analytical work serving the policy research needs of participants on the drivers of productivity growth.

This paper has been authorised for publication by Luiz de Mello, Director, Policy Studies Branch, Economics Department, Álvaro Santos Pereira, Director, Country Studies Branch, Economics Department, and Andrew Wyckoff, Director, Directorate for Science, Technology and Innovation.

OECD Productivity Working Papers should not be reported as representing the official views of the OECD or of its member countries. The opinions expressed and arguments employed are those of the author(s).

Comments on OECD Productivity Working Papers are welcome and may be sent to: productivity@oecd.org OECD Productivity Working Papers are published on: oe.cd/productivity

Series: OECD Productivity Working Paper Series

ISSN 2413-9424

Please cite this paper as:

Adrjan, P., Ciminelli, G., Judes, A., Koelle, M., Schwellnus, C. and Sinclair, T., "Will it stay or will it go? Analysing developments in telework during COVID-19 using online job postings data", OECD Productivity Working Papers, 2021-30, OECD Publishing, Paris.

This document and any map included herein are without prejudice to the status of or sovereignty over any territory, to the delimitation of international frontiers and boundaries and to the name of any territory, city or area.

The statistical data for Israel are supplied by and under the responsibility of the relevant Israeli authorities. The use of such data by the OECD is without prejudice to the status of the Golan Heights, East Jerusalem and Israeli settlements in the West Bank under the terms of international law.

(C) OECD (2021)

You can copy, download or print OECD content for your own use, and you can include excerpts from OECD publications, databases and multimedia products in your own documents, presentations, blogs, websites and teaching materials, provided that suitable acknowledgment of OECD as source and copyright owner is given. All requests for commercial use and translation rights should be submitted to PubRights@oecd.org. 


\section{ABSTRACT/RÉSUMÉ}

\section{Will it stay or will it go? Analysing developments in telework during COVID-19 using online job postings data}

The COVID-19 crisis has triggered a major shift towards telework and virtual interactions. This paper uses information on job postings from the online job site Indeed to analyse developments in the adoption of telework across 20 countries. It finds, first, that the incidence of advertised telework almost tripled during the pandemic, albeit with large differences both across sectors and across countries. Second, crosscountry differences are to a notable extent explained by differences in the extent to which governments restricted mobility during the pandemic. However, while the tightening of restrictions substantially raises advertised telework, their easing only modestly reverses the increase. Third, digital preparedness plays an important role in mediating the response of advertised telework to changes in restrictions. The tightening of restrictions has particularly large effects in sectors that are better prepared to adopt digital business models, while their easing has almost no effect in countries with high-quality digital infrastructure. Overall, these results suggest that telework is here to stay, especially in countries with high levels of digital preparedness. Public policies will need to adapt to reap the potential benefits for productivity and worker well-being.

Keywords: telework, mobility restrictions, digital infrastructure.

JEL classification codes: D23, E24, J23, G18, M50.

\section{Permanent ou transitoire ? Une analyse des évolutions du télétravail pendant la crise du COVID- 19 à l'aide des données d'emploi en ligne}

La crise du COVID-19 a déclenché une évolution majeure vers le télétravail et les interactions virtuelles. Ce document utilise des données sur les offres d'emploi du site d'emploi en ligne Indeed pour analyser l'évolution du télétravail dans les annonces dans 20 pays. II constate que l'incidence du télétravail dans les annonces a presque triplé pendant la pandémie, avec de grandes différences à la fois entre les secteurs et entre les pays. Les différences entre les pays s'expliquent dans une large mesure par les différences entre les restrictions de mobilité imposées par le gouvernement pendant la pandémie. Un durcissement des restrictions gouvernementales augmente la part de télétravail dans les annonces plus qu'un assouplissement équivalent ne le réduit. La baisse du télétravail dans les annonces en réponse à un assouplissement des restrictions est encore plus limitée dans les pays dotés d'infrastructures numériques de qualité. Dans l'ensemble, ces résultats suggèrent que le télétravail est là pour perdurer, en particulier dans les pays bien dotés en infrastructures numériques. Les politiques publiques devront être adaptées pour récolter les bénéfices potentiels pour la productivité et le bien-être des travailleurs.

Mots clés : télétravail, restrictions à la mobilité, infrastructure numérique.

Classification JEL : D23, E24, J23, G18, M50. 


\section{Table of contents}

Will it stay or will it go? Analysing developments in telework during COVID-19 using online job postings data

1. Introduction

2. Data and stylised facts

2.1. Data

2.2. Stylised facts

3.1. Government restrictions have acted as a catalyst of advertised telework

3.2. Digital preparedness mediates the response of telework to government restrictions $\quad 14$

4. Concluding remarks

\section{References}

Annex A. Additional tables and figures

\section{Tables}

Table A.1. Indeed job categories

Table A.2. List of keywords indicating advertised telework

\section{Figures}

Figure 1. The share of advertised telework has tripled since the beginning of the pandemic 8

Figure 2. The increase in advertised telework mostly reflects within-sector developments 9

Figure 3. The increase in advertised telework is largest in skill and digital-intensive services 10

Figure 4. Government restrictions boosted advertised telework $\quad 10$

Figure 5. Easing restrictions only modestly decreases telework on average across countries 13

Figure 6. Telework is more likely to persist in more digitally prepared countries $\quad 15$

Figure 7. The effect of tightening restrictions is concentrated in highly digitally prepared sectors 17

Figure 8. Advertised telework is predicted to stay substantially above its pre-pandemic level 19

Figure A.1. Job postings have held up better in sectors with low advertised telework in 2019

Figure A.2. COVID-19 fatalities and government restrictions have similar but independent effects 24

Figure A.3. Decreases in mobility are associated with a sharp rise in advertised telework

Figure A.4. The different effect of restrictions in low and high digitally prepared countries is robust 25

Figure A.5. Advertised telework followed similar trends across sectors before the pandemic 26

Figure A.6. In-sample forecasts of advertised telework has a good fit 26 


\section{Will it stay or will it go? Analysing developments in telework during COVID- 19 using online job postings data}

By Pawel Adrjan, Gabriele Ciminelli, Alexandre Judes, Michael Koelle, Cyrille Schwellnus and Tara Sinclair $^{1}$

\section{Introduction}

1. The COVID-19 crisis has led to major changes in production and consumer preferences, including a shift to telework and virtual interactions, accelerated digitalisation and the use of e-commerce and digital platforms. If these changes persist even after the pandemic recedes, businesses that are best able to adapt to these new ways of producing and consuming will likely expand while those that are unable to adapt will likely downsize or exit the market. Moreover, beyond within sector shifts in competitiveness across firms, the adoption of new ways of producing and consuming is likely to trigger a broader process of resource reallocation across locations and economic sectors.

2. This paper uses information on firms' online job postings from the job site Indeed to analyse the extent and drivers of the adoption of telework during the COVID-19 crisis and beyond, within and across sectors in 20 OECD countries. Job postings that advertise telework differ from measures of realised telework, as job postings relate to firms' future hires and do not measure telework adoption by their existing workforces. However, online job postings signal firms' expectations on future developments in telework, and as such provide the best available measure of its medium-term adoption, beyond ad-hoc arrangements adopted during COVID-19 related lockdowns. Surveys on managers' subjective expectations on future telework adoption do not have any financial or organisational consequences, whereas job postings represent an explicit commitment by firms to make telework available to the worker.

3. This paper adds to the existing body of evidence on the adoption of telework during the COVID19 crisis in several ways. First, it analyses the increase in advertised telework from a cross-country perspective, which allows the identification of the structural and institutional determinants of telework adoption, while most previous studies have focused on telework adoption in individual countries (Bloom,

\footnotetext{
${ }^{1}$ Corresponding authors: Pawel Adrjan (padrjan@indeed.com) from Indeed Hiring Lab and Regent's Park College, University of Oxford; Gabriele Ciminelli (Gabriele.Ciminelli@oecd.org), Michael Koelle (Michael.Koelle@oecd.org) and Cyrille Schwellnus (Cyrille.Schwellnus@oecd.org) all from the OECD Economics Department; Alexandre Judes (ajudes@indeed.com) from Indeed Hiring Lab, Tara Sinclair (taras@indeed.com) from Indeed Hiring Lab and The George Washington University. We are thankful for the excellent research assistance by Fabian Hans, AlassaneAnand Ndour, Allison Shrivastava at Indeed and Stefanos Tyros at the OECD. We thank Sarah Michelson Sarfati for excellent editorial support.
} 
2020; Taneja, Mizen, \& Bloom, 2021). ${ }^{2}$ Second, the paper explicitly accounts for cross-sector differences in the adoption of telework. This allows identifying potential reallocation pressures more precisely than aggregate cross-country data, on which most previous studies have been based (Barrero, Bloom, \& Davis, 2021). For instance, large increases in advertised telework in digital-intensive sectors may require substantial adaptation of work practices by lagging firms. Third, the paper tracks developments in job postings advertising telework in near real time whereas most surveys become available only with a publication lag (Ker et al, 2021).

4. The main results of the paper are as follows:

- Firms are expecting telework to persist, with the incidence of advertised telework being almost three times higher in September 2021 (nearly 71/2 percent) than in January 2020 (about 21/2 percent) on average across countries.

- The increase in advertised telework is most pronounced in skill and digital-intensive sectors, such as IT-related services and insurance. But there is so far no evidence that the increase in telework is triggering shifts in activity across broad economic sectors.

- Across countries, the increase in advertised telework between 2019 and the pandemic period ranges between 0 in Japan to about 7 percentage points in Ireland. To a large extent, these crosscountry differences can be explained by differences in the extent to which governments restricted mobility during the pandemic.

- On average across countries, the tightening of government restrictions raises advertised telework by more than the equivalent easing reduces it, suggesting that advertised telework will persist even once restrictions are fully lifted.

- Digital preparedness plays an important role in mediating the response of advertised telework to changes in government restrictions.

- The response of advertised telework to tightening restrictions is similar across countries but the response to easing restrictions is (modestly) negative only in countries with low levels of broadband internet penetration.

- The increase in advertised telework following a tightening of restrictions is largely concentrated in sectors that are better prepared to adopt digital business models.

5. These results suggest that telework is likely here to stay and may grow even further in highly digitally-prepared countries and sectors. Governments in countries that are well behind in terms of telework adoption should encourage its uptake, given that survey evidence suggests that hybrid work arrangements may raise both productivity and workers' well-being (Barrero, Bloom, \& Davis, 2021). Moreover, a broader adoption of telework may help governments to meet decarbonisation targets by reducing commutingrelated $\mathrm{CO}_{2}$ emissions. It may also allow firms to attract the best global talent in a context where "telemigration" may become increasingly important (Baldwin \& Forslid, 2020).

6. At the same time, policy makers will also have to deal with increased reallocation pressure, as technological and managerial preparedness for telework adoption differs significantly across firms, workers and geographical areas (Criscuolo, Gal, Leidecker, Losma, \& Nicoletti, 2021). Moreover, the rise of telework risks widening social and spatial inequalities, as the shifting economic geography from central business districts towards residential areas and suburbs comes with adjustment costs. Governments should smooth and enable this transition by promoting public and private investment that ensures appropriate levels of digital and physical infrastructure across urban and rural areas, and by fostering digital skills for the broader workforce.

\footnotetext{
${ }^{2}$ A notable exception is OECD (2020).
} 
7. The remainder of the paper is structured as follows. Section 2 describes the online job postings data from Indeed as well as the other data used in the analysis and presents the key stylised facts. Section 3 formally investigates the determinants of advertised telework during the COVID-19 pandemic and Section 4 concludes.

\section{Data and stylised facts}

8. This section presents the data used in the paper and establishes a set of key stylised facts regarding the evolution of advertised telework during the COVID-19 pandemic. The sample includes 20 OECD countries (Australia, Austria, Belgium, Canada, France, Germany, Ireland, Israel, Italy, Japan, Luxembourg, Mexico, Netherlands, New Zealand, Poland, Spain, Sweden, Switzerland, the United Kingdom and the United States) and spans the period January 2019 through September 2021. All country average statistics reported in this paper refer to the 20 country unweighted average.

\subsection{Data}

9. Data on job postings advertising telework come from the online job site Indeed. Indeed aggregates job advertisements posted directly on its proprietary website as well as thousands of online job boards, career sites and recruiter listings. Job offers are de-duplicated so that when the same job is collected from multiple sources it is shown only once. However, despite the de-duplication process, the job postings on Indeed do not reflect a precise number of available jobs, as an opening may remain online for a period of time after being filled or may not be advertised online at all. Additionally, employers can use a single job posting for multiple job openings. Internal and external analysis nonetheless suggests that the number of job postings on Indeed are broadly in line with job vacancies from government surveys (Adrjan \& Lydon, 2019; Kennedy, 2021, Ens et al., 2021).

10. By extracting key information from the job postings, such as job title, posting date and other keywords, the data can be used for research and analysis. The information extraction is based on text analysis using state-of-the-art proprietary algorithms. This paper uses data at the country-sector-monthlevel on (1) on the overall number of postings and (2) the share of job postings advertising telework (those that explicitly mention the possibility to telework in the title, description or location). ${ }^{3,4}$ The overall number of postings is seasonally adjusted but the share of job postings advertising telework is not. ${ }^{5}$ Country-level statistics are obtained by aggregating over the different sectors using their shares in a country's overall job postings as weights.

11. The dataset is complemented with other variables that may potentially explain the changes in advertised telework during the pandemic. The level of government-imposed restrictions is approximated by the stringency index from the Oxford COVID-19 Government Response Tracker (Hale et al., 2021). ${ }^{6}$

\footnotetext{
${ }^{3}$ Indeed classifies job postings into 55 job categories that do not directly correspond to standard industry or occupation classifications, which we call 'sectors' for short (see Annex Table A.1 for a full listing of job categories).

${ }^{4}$ The telework-specific keywords used by Indeed to identify teleworkable job ads are reported in Annex Table A.2.

${ }^{5}$ In constructing the share of job postings advertising telework, neither the numerator (the number of job postings advertising telework) nor the denominator (the overall number of job postings) is seasonally adjusted.

${ }^{6}$ The Oxford COVID-19 stringency index is the weighted mean of different sub-indexes measuring the intensity of (i) school closures, (ii) workplace closures, (iii) restrictions to public events, (iv) restrictions to gatherings, (v) closure of public transport, (vi) stay at home requirements, (vii) restrictions to internal movements, (iix) controls to international travel, and (ix) public information campaigns on a 0-100 scale. When restrictions apply uniformly across the country, the different sub-indexes receive equal weights. If instead some restrictions are different across states/regions, the
} 
Data on cumulative cases and deaths, used to measure the severity of the pandemic, come from the same source. Data on changes in people's visits to shops, restaurants as well as to cultural and entertainment venues, used to measure the joint effects on mobility of explicit government restrictions and voluntary changes in behaviour, are sourced from Google COVID-19 Community Mobility Reports. ${ }^{7}$ All these variables are available at the country-month-level and are used to investigate the direct effects of the pandemic on telework.

12. To proxy digital preparedness across countries, a time-invariant variable on broadband penetration (fixed and mobile broadband subscriptions per 100,000 inhabitants) is sourced from the OECD Broadband Portal. To proxy digital preparedness across sectors, a country and time-invariant variable measuring the share of jobs that can be carried out digitally is constructed from the classification of teleworkable and nonteleworkable jobs developed by Dingel \& Neiman (2020). ${ }^{8}$

13. Additional time-invariant variables on country characteristics are sourced to investigate other potential interactions between the pandemic and country structural factors. Data on the average numeracy skills of the workforce are sourced from the OECD Program for International Assessment of Adult Competencies (OECD, 2021b), while cross-country scores of management quality in manufacturing firms are sourced from the World Management Survey portal.

\subsection{Stylised facts}

14. On average across the countries covered by the analysis, the share of advertised telework (job advertisements explicitly mentioning telework as a share of all job advertisements) has tripled since the onset of the pandemic (Figure 1). It jumped by more than 2 percentage points between January and May 2020, as governments in most countries imposed strict mobility restrictions, and continued to grow uninterruptedly to $7.9 \%$ in April 2021 despite the easing of government restrictions over the summer of 2020 and early 2021. Since May 2021, the average share of advertised telework has stabilised at around $71 / 2$ percent of overall job postings. The increase in advertised telework may reflect a shift in remote working of jobs that already existed before the pandemic as well as the creation of new jobs in response to accelerated digitalisation of the economy during the pandemic.

15. The current level of advertised telework implies a large gap with the share of jobs that were done from home at the peak of the pandemic. A number of studies estimate the share of workers teleworking at the peak of the pandemic at around 40-50\% (Taneja, Mizen, \& Bloom; 2021; Bloom, 2020), which is broadly consistent with estimates of telework potential in high-income countries (Dingel \& Neiman, 2020). While remote working may have been adopted quickly during lockdowns in order to allow businesses to keep activity going, employers may be more reticent to advertise jobs as teleworkable, as this may be perceived by jobseekers as implying a medium-term commitment to telework, lasting beyond the pandemic. In this sense, changes in advertised telework in response to the pandemic signal a more structural re-organisation

respective sub-index codes the intensity of the restriction in the most restricted region/state but gets a lower weight in the overall index.

${ }^{7}$ Different from the Oxford COVID-19 stringency index, Google mobility data take into account of all the different trends at the subnational level by averaging across different metropolitan areas within a country.

8 Dingel \& Neiman (2020) classify each O*NET occupation into teleworkable or non-teleworkable based on whether they can be carried out entirely at home. To derive a sector-level measure of teleworkability, O*NET occupations are first aggregated at the US Standard Occupational Classification (SOC)-level. Each SOC occupation is then matched to one of the 55 Indeed sectors. Next, each of the 55 Indeed sectors is assigned a teleworkability score. This is done by aggregating the teleworkability scores of SOC occupations using employment shares of each SOC occupation within the given Indeed sector as weights. See Chen (2020) for a similar approach. 
of work than short-term shifts in and out of telework in response to lockdowns that are captured by measures of realised telework hours. ${ }^{9}$

\section{Figure 1. The share of advertised telework has tripled since the beginning of the pandemic}

Share of teleworkable job postings and government restrictions index, average country

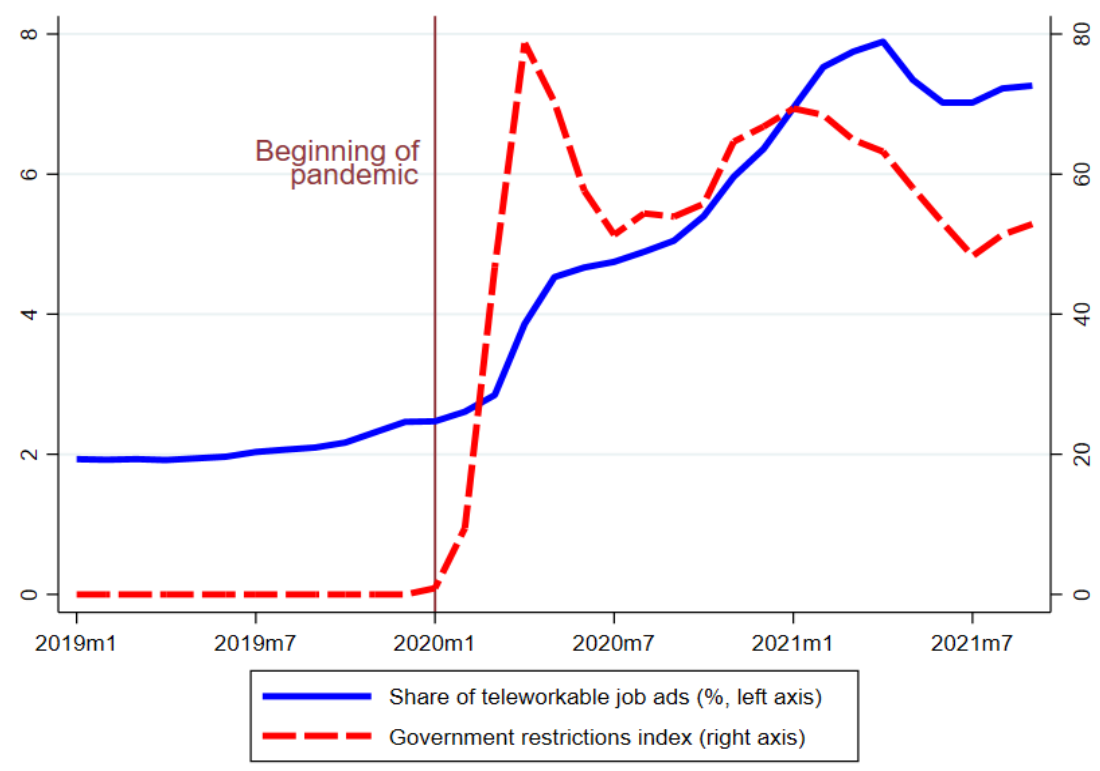

Note: The figure plots the average values of the share of teleworkable job postings and of the government restrictions index across countries. Source: Indeed, Hale et al. (2021) and OECD calculations.

16. The increase in advertised telework during the pandemic ranges from around 0 in Japan to around 7 percentage points in Ireland, suggesting that structural and policy differences may have had a large impact on the adoption of telework (Figure 2). Between-sector reallocation (the shift of job postings between sectors with different degrees of teleworkability) has only played a minor role in the overall increase in advertised telework. In a number of countries, job postings in low-remote, in-person job categories, such as healthcare, cleaning or retail have even held up better and grown faster than postings in other categories (Annex Figure A.1). Part of the reason is that many governments considered these jobs essential, granting workers exemptions from mobility restrictions. Another reason is that some low-remote

\footnotetext{
9 The large gap with realised telework may also be partly explained by the possibility of telework being implicitly assumed in some occupations rather than explicitly mentioned in job adverts. Moreover, advertised telework is expressed as a share of all job adverts rather than employment, which could understate the incidence of telework if teleworkable occupations have a lower vacancy rate than non-teleworkable ones. Adrjan (2020) documents substantial increases in jobseeker interest in remote work which suggests worker interest in taking up more telework. For countryspecific studies of the role of remote work in Indeed job postings see Adrjan (2020), Judes (2021), Kolko (2021). However, the large gap in levels notwithstanding, over the medium term, changes in advertised and realised telework tend to be correlated. For instance, on average across the European countries covered in this paper, both advertised and realised telework increased roughly by a factor of two between 2019 and 2020. Realised telework is sourced from Eurostat's EU Labour Force Survey (LFS) and refers to teleworking for a majority of hours over the past month. It covers not only newly hired but also incumbent workers. The comparison refers to the average incidence of telework for the years 2020 compared to 2019 for a common sample of 11 European countries. Over this time period, advertised telework increased by a factor of 2.2. Realised telework equally increased by a factor of 2.2 on average across countries, reaching $15 \%$ in 2020 , the latest available datapoint in the EU-LFS.
} 
occupations, like hospitality and retail, suffered major job losses during the pandemic and have therefore seen a stronger rebound in recruitment as restrictions eased. The remainder of the paper focuses on within-sector changes in advertised telework that are less affected by such transitory factors and account for the overwhelming part of overall changes.

\section{Figure 2. The increase in advertised telework mostly reflects within-sector developments}

Shift-share decomposition of the increase in advertised telework, pandemic average minus 2019 average

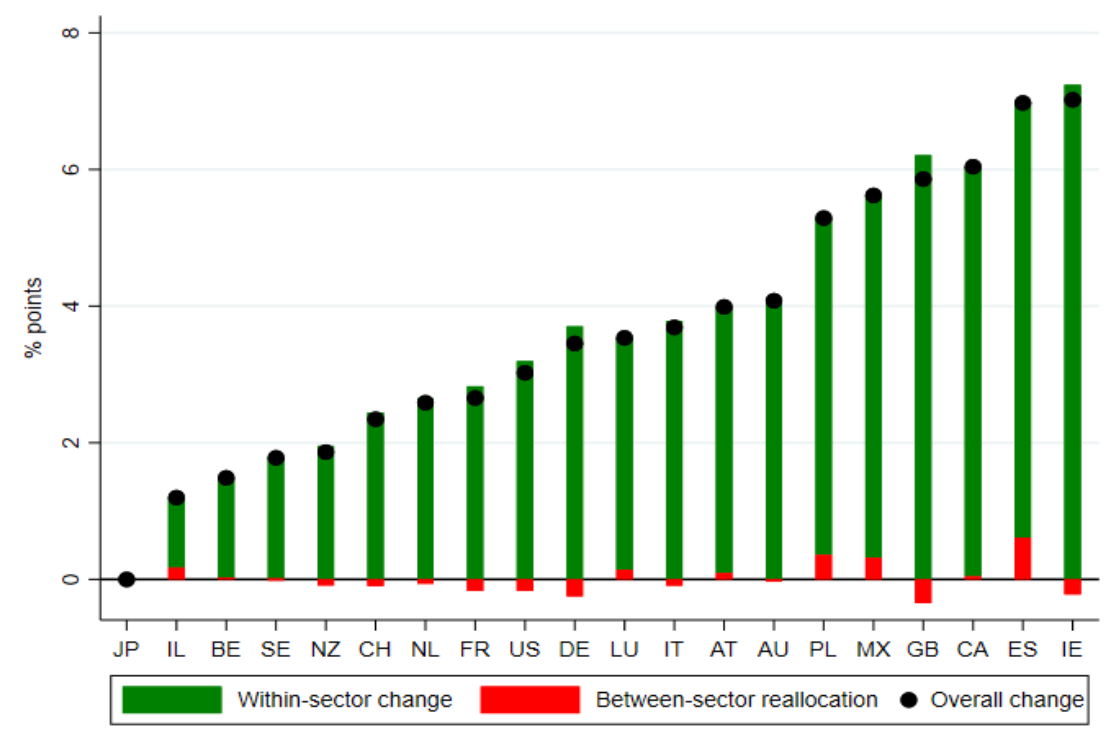

Note: The shift-share decomposition is based on the equation $F_{t}-F_{t-1}=\sum_{i} \quad \underline{s}_{i}\left(f_{i t}-f_{i t-1}\right)+\sum_{i} \quad f_{i}\left(s_{i t}-s_{i t-1}\right)$ where $F$ is the aggregate incidence of advertised telework; $s_{i t}$ is the share of postings of sector $i$ in period $t$ in total postings; $s_{i}$ is the average share of postings of sector $i$ in total postings over the period $t-1$ to $t ; f_{i t}$ is the incidence of advertised telework in sector $i$ in period $t$; and $f_{i}$ is the average incidence of advertised telework in sector $i$ over the period $t-1$ to $t$. The first term on the right-hand side of the equation denotes the within-sector change in telework while the second term denotes between-sector reallocation. The pandemic average covers January 2020 through September 2021. Source: Indeed and OECD calculations.

17. On average across countries, advertised telework increased in almost all sectors but the increase was particularly pronounced in skill-intensive and/or digital-intensive services sectors (Figure 3). For instance, the share of advertised telework increased by about 11 percentage points in the software development and marketing sectors but by less than 1 percentage point in the food, retail, driving and manufacturing sectors.

18. Cross-country differences in government restrictions, approximated by the stringency index from the Oxford COVID-19 Government Response Tracker, explain about a third of the cross-country pattern in the increase of advertised telework during the pandemic (Figure 4). In countries where government restrictions were high, such as Ireland, Italy, Spain and the United Kingdom, advertised telework increased substantially more than in countries where restrictions were low, such as Japan and New Zealand. 
Figure 3. The increase in advertised telework is largest in skill and digital-intensive services Change in share of advertised telework, pandemic average minus 2019 average, average country, \% points
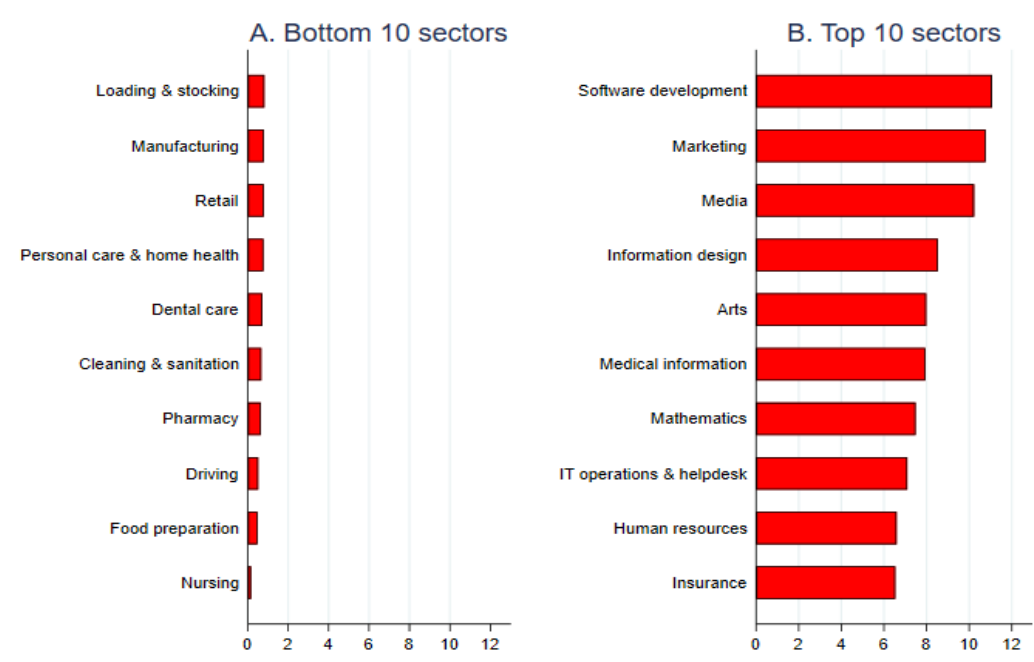

Note: The pandemic average covers January 2020 through September 2021.

Source: Indeed and OECD calculations.

Figure 4. Government restrictions boosted advertised telework

Mean government restrictions index and change in advertised telework

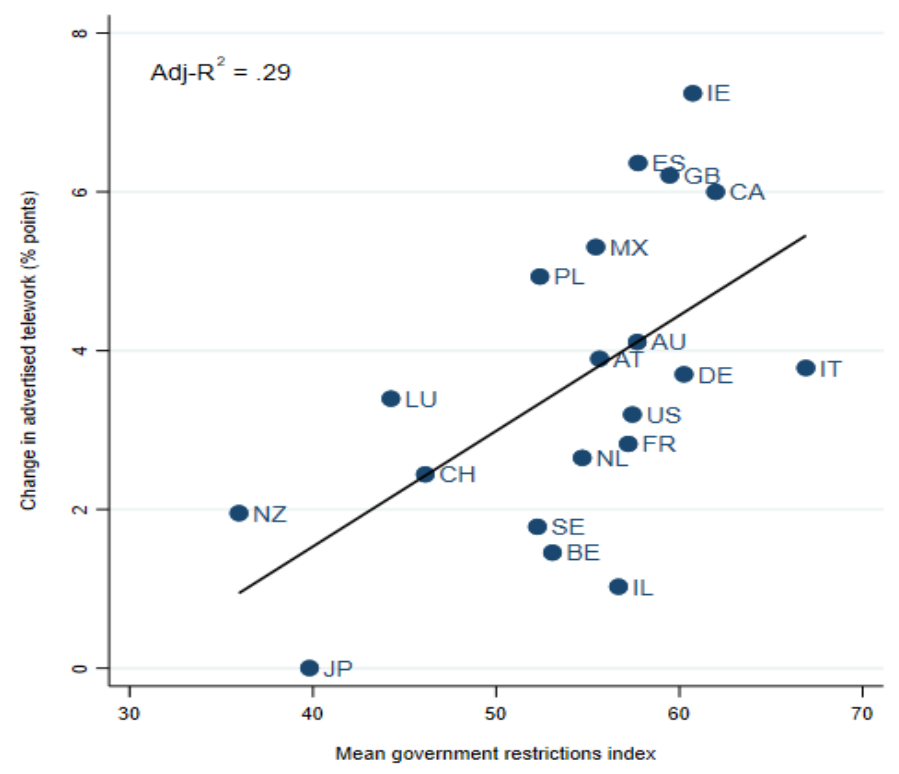

Note: The government restriction index is calculated as the mean value of the Oxford Stringency Index over the January 2020 to September 2021 period. The change in advertised telework during the pandemic refers to the within-sector change in advertised telework during the pandemic, as calculated in Figure 3.

Source: Indeed, Hale et al. (2021) and OECD calculations. 


\section{Determinants of the increase in telework}

19. This section formally analyses the response of advertised telework to the pandemic and the associated government restrictions. The empirical analysis is based on the local projections method, which allows (i) estimating the dynamic response of advertised telework to a change in government-imposed mobility restrictions over a long horizon; and (ii) exploring the differential response of tightening and easing restrictions, as well as the heterogeneous responses across countries and sectors (Box 1).

\section{Box 1. Empirical framework: the local projections method}

This paper draws on the local projections method to analyse the dynamic response of advertised telework to a change in government regulation, approximated by the Oxford COVID-19 government stringency index. The local projections method was pioneered by Jordà (2005) and has been widely used as a flexible alternative to autoregressive distributed lag specifications (Aurbach \& Gorodnichenko 2012; Romer \& Romer, 2017; Ramey \& Zubairy, 2018). It consists of directly obtaining the response of the dependent variable at period $t+k$ to the shock at time $t$ by estimating a different regression specification for each horizon. Impulse response functions (IRFs) are constructed by plotting the estimated coefficients as point estimates and their standard errors as confidence bands.

\section{Symmetric effects}

In a first step, positive and negative changes in the Oxford stringency index (tightening and easing restrictions respectively) are assumed to have symmetric effects on the share of job postings advertising telework. For each $k=0, \ldots, 5$, the following regression specification is estimated:

$$
y_{i, t+k}-y_{i, t-1}=\mu_{i}+\beta^{k} \Delta x_{i, t}+\sum_{f=1}^{k} \varphi^{f} \Delta x_{i, t+f}+\sum_{l=1}^{2} \sigma^{l} \Delta x_{i, t-l}+\varepsilon_{i, t}
$$

where the subscripts $i$ and $t$ indicate country and time respectively, $y_{i, t}$ is the share of job ads advertising telework in country $i$ at time $t, \mu_{i}$ are country fixed effects, $\Delta$ is the first difference operator, $x_{i, t}$ is the Oxford stringency index and $\varepsilon_{i, t}$ is an error term.

The regression specification includes forward shock variables $\left(\sum_{f=1}^{k} \varphi^{f} \Delta x_{i, t+f}\right)$ to control for changes in government regulation happening within the $t+k$ horizon that are not captured by the shock variable at time $t\left(\Delta x_{i, t}\right)$ and whose omission could bias the estimates (Teulings \& Zubanov, 2014). Because changes in government regulation may be autocorrelated, the regression specification also includes two lags of the shock variable $\left(\sum_{l=1}^{2} \sigma^{l} \Delta x_{i, t-l}\right) \cdot{ }^{1}$ The identifying assumption is that changes in government regulation are exogenous to changes in advertised telework. Coefficients are estimated through OLS. Standard errors are heteroskedasticity-robust. IRFs showing the effect of a 1 standard deviation positive change in the government restrictions index are constructed plotting the estimated $\beta^{k}$ coefficients for the point estimate (blue solid lines) and 1.6 standard errors for the confidence bands (red dashed lines).

\section{Asymmetric effects}

In a second step, advertised telework is allowed to respond differently to positive and negative changes in the Oxford stringency index. For each $k=0, . ., 5$, the following regression specification is estimated: 


$$
\begin{aligned}
y_{i, t+k}-y_{i, t-1}= & \mu_{i}+\beta^{p, k} x_{i, t}^{p}+\beta^{n, k} x_{i, t}^{n}+\sum_{f=1}^{k}\left(\varphi^{p, f} x_{i, t}^{p}+\varphi^{n, f} x_{i, t}^{n}\right) \\
& +\sum_{l=1}^{2}\left(\sigma^{p, l} x_{i, t-l}^{p}+\sigma^{n, l} x_{i, t-l}^{n}\right)+\varepsilon_{i, t}
\end{aligned}
$$

where $x_{i, t}^{p}$ and $x_{i, t}^{n}$ respectively denote positive and negative changes in the stringency index and the rest of the notation is as in Equation (1). IRFs are obtained plotting the $\beta^{p, k}$ and $\beta^{n, k}$ coefficients and their respective standard errors.

${ }^{1}$ The results in this paper are robust to using different lag structures and to not include forward shock variables (estimates available upon request).

\subsection{Government restrictions have acted as a catalyst of advertised telework}

20. Advertised telework responds strongly to government-imposed mobility restrictions (Figure 5). On average across countries, a one-standard deviation change in the government restriction index (equal to about 15 points on a scale of 100 ) leads to a 0.5 percentage point change in the share of job ads advertising telework over the five subsequent months (Panel A). This response is driven by positive changes (tightening restrictions), which lead to a persistent increase in the share of advertised telework (Panel B1).

21. Negative changes (easing restrictions) induce a more modest and less persistent decline in advertised telework (Panel B2). This suggests that changes in advertised telework are highly persistent, in the sense that advertised telework is catalysed by restrictions but does not revert to its previous level even when restrictions are lifted. This could reflect irreversible investments in digital infrastructure, changes in management and learning on the part of businesses and/or increased demand for telework on the part of workers. 
Figure 5. Easing restrictions only modestly decreases telework on average across countries

Effect of a standard deviation change in the government restriction index on advertised telework
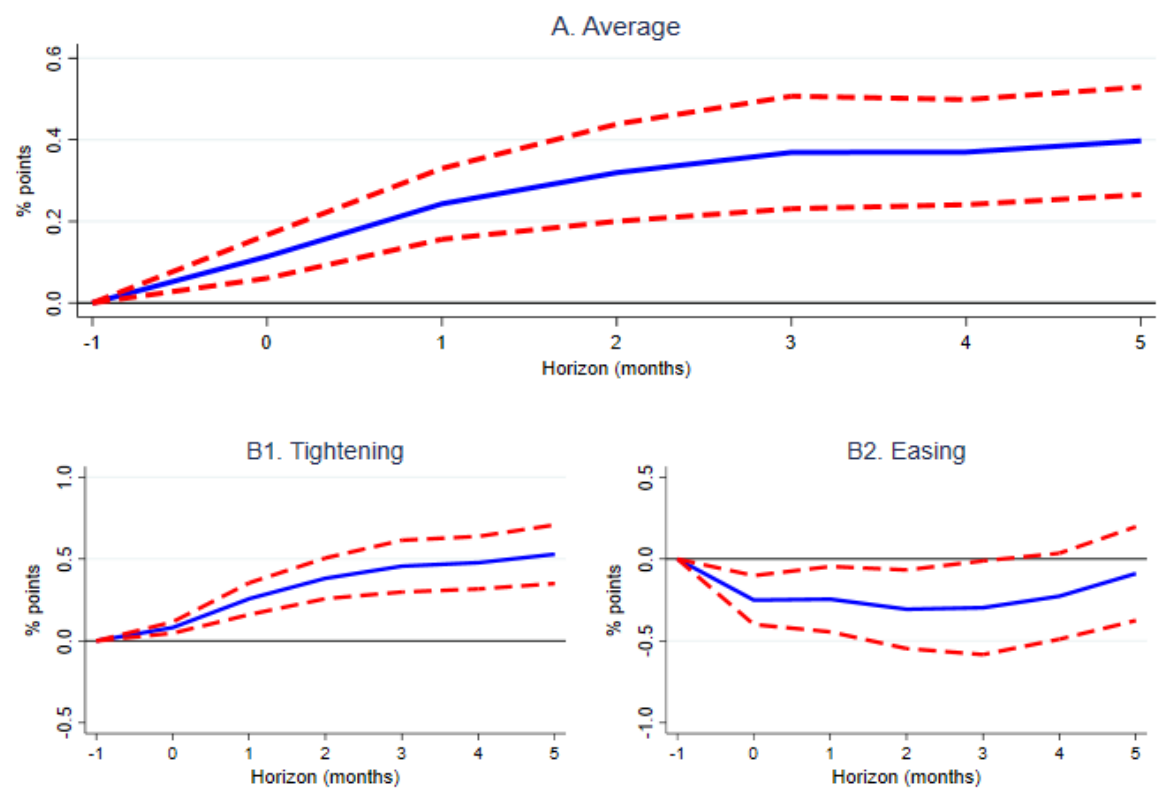

Note: The figure shows the cumulative effect of a change in the government restrictions index on the share of job postings advertising telework, over a 6-month horizon. Panel A reports the average effect, while Panels B1 and B2 respectively report the effect of a positive and a negative change. Blue solid lines denote point estimates, while red dashed lines are $90 \%$ confidence bands. Refer to Box 1 for details on the econometric methodology.

Source: OECD calculations based on data from Indeed and Hale et al. (2021).

22. The weak response of advertised telework to easing government restrictions does not seem to reflect expectations that restrictions may be re-introduced in the near term. Businesses may limit adjustments in the share of advertised telework if they perceive a high likelihood of the re-introduction of restrictions in the near term, as it may have been the case during the summer of 2020. However, distinguishing between the response to easing restrictions before and after the start of the vaccination campaign, which may have had an impact on firms' expectation about the duration of new easing of regulation, suggests that there is no significant difference, with telework responding only weakly to easing restrictions in both periods. ${ }^{10}$

23. The baseline results are also robust to controlling for the severity of the pandemic. When the effects of a change in restrictions and those of a change in the incidence of COVID-19 fatalities are estimated jointly, both have important and qualitatively similar effects (Annex Figure A.2): a worsening of the pandemic (measured either through positive changes in the stringency index or an increase of COVID19 fatalities) has large and persistent effects on advertised telework, while the receding of the pandemic

10 To estimate whether the start of the vaccination campaign influenced the response of advertised telework to an easing of government regulation, two alternative models are estimated. The first allows the start of the vaccination campaign to have a discrete effect on the relation between easing regulation and advertised telework (dummy variable approach). The second allows higher vaccination rates to have proportionally larger effects on such a relation (interaction model approach). In both cases the resulting impulse response functions are inconclusive: the response of advertised telework to easing restrictions is weak and not statistically significant. 
has weaker and less persistent effects. These additional results suggest that explicit government restrictions (measured by the stringency index) and voluntary changes in behaviour stemming from virus outbreaks (measured by the incidence of COVID-19 fatalities) both acted as a catalyst of advertised telework during the pandemic.

24. The effect of the pandemic on advertised telework is estimated to be even larger when the change in mobility (measured as the frequency of visits to shops, restaurants and entertainment venues), which combine government restrictions and voluntary changes in behaviour, is used as the main explanatory variable (Annex Figure A.3). ${ }^{11}$ The results using this alternative measure are qualitatively in line to those obtained when looking at the effects of government regulation: a reduction in mobility is associated with a strong and persistent rise in advertised telework, while an increase in mobility of the same magnitude is only weakly associated with a decrease in telework.

\subsection{Digital preparedness mediates the response of telework to government restrictions}

25. The response of advertised telework to the easing of government restrictions is close to 0 and statistically insignificant in countries with high levels of digital preparedness, as measured by broadband internet penetration, while it is negative and statistically significant in countries with low penetration. (Figure 6). For instance, in Italy, a country with a relatively low level of digital intensity, the share of job ads advertising telework increased by over 9 percentage points from January 2020 to April 2021, but declined by more than 5 percentage points over the following five months as restrictions were gradually eased. This pattern suggests that in less digitally prepared countries, telework was mainly embraced as a temporary backstop to keep the economy going during the pandemic, but may be partly rolled back once the pandemic recedes. On the other hand, in the US, where digital penetration is high, the share of job ads advertising telework increased by about 7 percentage points from January 2020 to January 2021, when restrictions reached their peak, and remained around this level during the subsequent easing period, pointing to a more persistent change in the organisation of work. In contrast to the response of advertised telework to easing restrictions, the response to tightening restrictions does not appear to digital preparedness.

26. The response of advertised telework to government restrictions is not systematically related to other plausible telework-enabling factors, such as average skills of the workforce and management quality (results available upon request). ${ }^{12}$ This suggests that the average level of skills and management quality are not a binding constraint on the take-up of telework in the sample of mostly high-income countries covered in this paper.

\footnotetext{
${ }^{11}$ Using mobility data to investigate the effects of the pandemic on advertised telework has the advantage that these data reflect different subnational trends, while the government stringency index only measures restrictions in the most restricted region/state. On the other hand, mobility may respond endogenously to changes in telework (as people who work from home may make fewer trips to restaurants, cafes and shops). Hence, this paper uses the government restrictions index as the main variable of interest.

12 Moreover, accounting for skills and management quality does not affect the result that the easing of restrictions has smaller negative effects on advertised telework in countries with low levels of broadband internet penetration (Annex Figure A.4).
} 
Figure 6. Telework is more likely to persist in more digitally prepared countries

Effect of changes in government restrictions in countries with high and low levels of digital preparedness
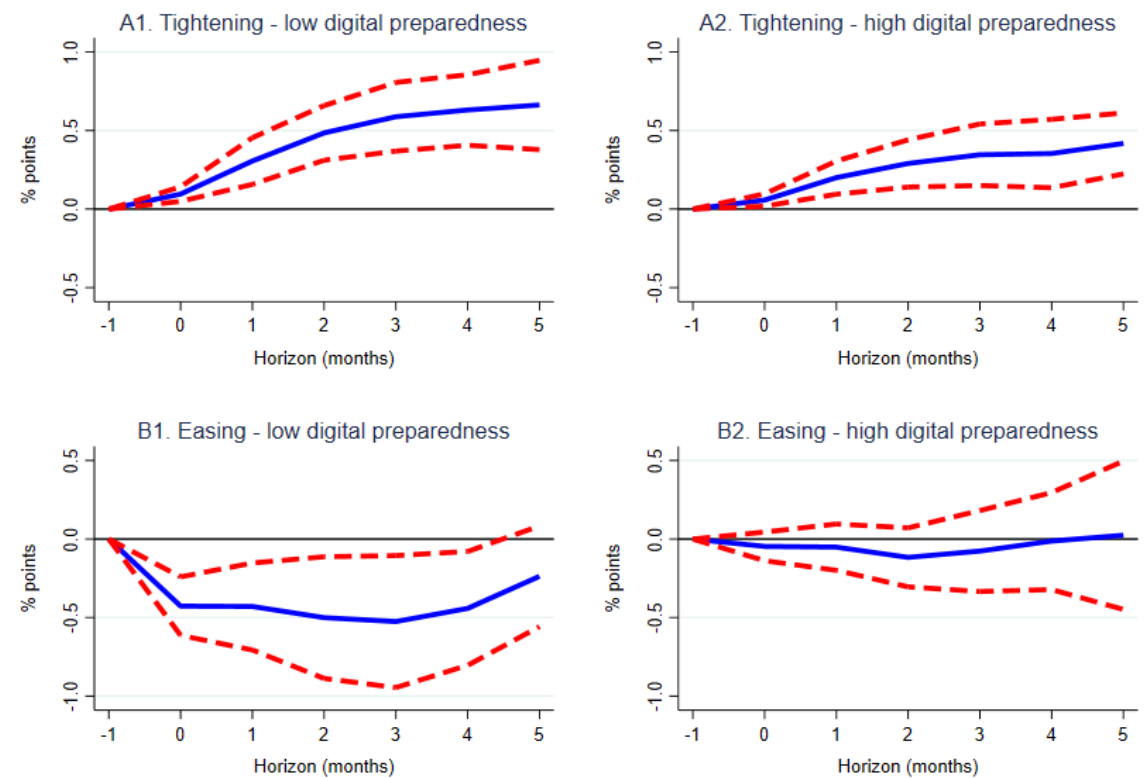

Note: The figure shows the cumulative effect of positive and negative changes in the government restrictions index on the share of job postings advertising telework, over a 6-month period, in countries with a low and a high level of digital preparedness, measured by broadband internet penetration. Countries with low (high) preparedness are defined as those in which the number of per capita broadband subscriptions is below (above) the sample median. Blue solid lines denote point estimates, while red dashed lines are $90 \%$ confidence bands. Refer to Box 1 for details on the econometric methodology.

Source: OECD calculations based on data from Indeed, Hale et al. (2021) and the OECD Broadband Portal.

27. Results from sector-level analyses confirm that digital preparedness is a key factor determining the persistence of advertised telework. Sector-level analyses allow using differences in digital preparedness across sectors rather than countries to identify its mediating effects on the response of advertised telework to changes in government-imposed mobility restrictions. Results are less likely to be affected by potential omitted determinants at the country-level, including the degree to which countries are specialised on highly-digitalised sectors. The patterns uncovered by this analysis suggest that telework may stabilise at structurally higher levels not only in countries with better digital infrastructure but also in sectors with higher digital preparedness within the same country (Box 2).

\section{Box 2. Sector-level analysis}

\section{Approach}

The country-level analysis described in Box 1 is complemented with a sector-level analysis which exploits the full depth of the Indeed dataset by exploring potential heterogeneities in the effect of government regulation on advertised telework across sectors. The Indeed dataset covers 55 sectors, which crucially differ in their level of digital preparedness, as measured by the share of occupations that can be carried out digitally. ${ }^{1}$ 
To investigate whether digital preparedness mediates the interaction between government regulation and the adoption of telework across sectors, this paper adopts a differences-in-differences approach in the spirit of Rajan \& Zingales (1998). This approach consists of employing digital preparedness (which is fixed across countries and time) as a sector-level exposure variable determining the intensity of the treatment (where the treatment itself is given by the change in government restrictions). The identifying assumption is that advertised telework was following similar trends in sectors with different levels of digital preparedness before the pandemic hit, which is verified in Annex Figure A.5. ${ }^{2}$

Another key advantage of this difference-in-differences analysis is that it permits to include country-bytime fixed effects that control for any unobservable country-specific development that may affect the level of advertised telework uniformly across sectors, as well as country-by-sector fixed effects that capture country-sector-specific trends. The analysis still relies on the local projection method to trace out the dynamic effects of a change in government regulation. The estimating equation is as follows:

$$
\begin{gathered}
y_{i, j, t+k}-y_{i, j, t-1}=\mu_{i, j}+\beta^{p, k} x_{i, t}^{p} * D_{j}+\beta^{n, k} x_{i, t}^{n} * D_{j}+ \\
+\sum_{f=1}^{k}\left(\varphi^{p, f} x_{i, t}^{p} * D_{j}+\varphi^{n, f} x_{i, t}^{n} * D_{j}\right)+\sum_{l=1}^{2}\left(\sigma^{p, l} x_{i, t-l}^{p} * D_{j}+\sigma^{n, l} x_{i, t-l}^{n} * D_{j}\right)+\tau_{i, t}+\varepsilon_{i, j, t}
\end{gathered}
$$

where the subscripts $i, j$ and $t$ indicate country, sector and time respectively, $y_{i, j, t}$ is the share of job ads advertising telework in sector $j$ of country $i$ at time $t, \mu_{i, j}$ are country-sector fixed effects, $\Delta$ is the first difference operator, $x_{i, t}^{p}$ and $x_{i, t}^{n}$ respectively denote positive and negative changes in the government stringency index, $D_{j}$ is the share of jobs in sector $j$ that can be carried out digitally (digital preparedness), $\tau_{i, t}$ are country-by-time effects and $\varepsilon_{i, j, t}$ is an error term. As in the country-level analysis, the regression specification includes forward shock variables and two lags of the shock variables (refer to Box 1 for more details).

$\beta^{p, k}$ and $\beta^{n, k}$ are the coefficients of interest. Because the regression includes country-time fixed effects, which absorb the average effect of changes in government regulation, $\beta^{p, k}$ and $\beta^{n, k}$ measure the differential effects of such changes across sectors. To interpret them, they are standardized to report the differential effect of a 1 standard deviation change in the government stringency index between the average industries in the two groups of those with a high and a low level of digital preparedness (measured as those in, respectively, the upper and lower terciles of the variable measuring the share of jobs that can be carried out digitally).

IRFs are obtained plotting the $\beta^{p, k}$ and $\beta^{n, k}$ coefficients for the point estimate and their respective standard errors to obtain $90 \%$ confidence bands. Coefficients are estimated through OLS. Standard errors are double-clustered at the country and time levels.

\section{Results}

Tightening restrictions have significantly larger effects on the share of advertised telework in more digitally prepared sectors (Figure 7). This suggests that the pandemic has opened up a wedge in the adoption of telework across sectors, unlocking the potential for telework in highly digitally-prepared sectors. On the other hand, there is no difference between sectors in the response of advertised telework to easing government restrictions, suggesting that the wedge opened up by the pandemic will not be reabsorbed even if restrictions will be completely lifted. Overall, these results imply that telework will stabilize at sharply different levels across sectors within the same country in the medium-term. 


\section{Figure 7. The effect of tightening restrictions is concentrated in highly digitally prepared sectors}

\section{Differential effects of changes in government restrictions between sectors with high and low digital preparedness}
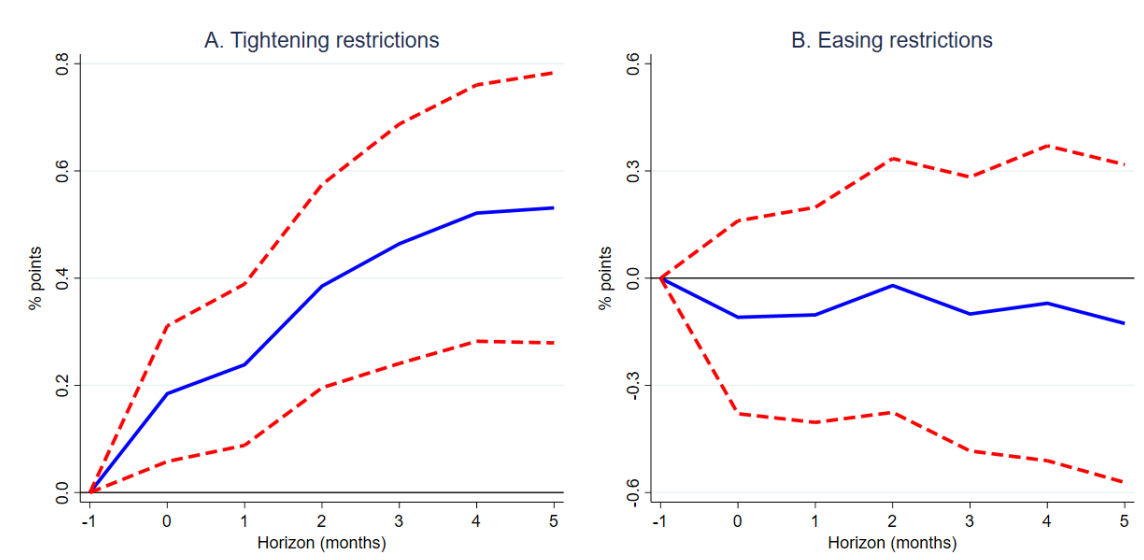

Note: The figure shows the differential effect of tightening and easing changes of the government restrictions index across between a sector with a high and one with a low level of digital preparedness, over a 6-month period. Digital preparedness is defined as the share of jobs that can be done digitally. A sector having a high (low) score in digital preparedness is defined as one having the mean value of the share of jobs that can be done digitally among sectors in the upper (lower) tercile of the distribution. Blue solid lines denote point estimates, while red dashed lines are $90 \%$ confidence bands. Point estimates and confidence bands are smoothed to show the 3-month moving average. Source: OECD calculations based on data from Indeed, Hale et al. (2021) and Dingel \& Neiman (2020).

${ }^{1}$ For instance, in the insurance and legal sectors over $90 \%$ of jobs could be carried out digitally, whereas in the therapy and customer service sectors the same share ranged between $20 \%$ and $40 \%$. See Section 2 for details on how the variable measuring the share of occupations that can be carried out digitally is constructed.

${ }^{2}$ Annex Figure A.5 shows that advertised telework was following a slightly increasing trend in both high and mid digital intensity sectors before the pandemic hit. Advertised telework was instead flat in low digital intensity sectors, which may question the validity of the parallel trends assumption in the overall group of sectors. However, the results presented in this paper are very similar when low digital intensity sectors are excluded from the analysis (estimates available upon request). 


\section{Concluding remarks}

28. This paper documents a substantial increase in the share of job postings advertising telework following the COVID-19 pandemic. Such increase, which may reflect a shift to remote working of jobs that already existed before the pandemic as well as the creation of new jobs in response to the accelerate digitalisation of the economy, has been very heterogeneous both across sectors and across countries. These differences can to a large extent be explained by a combination of differences in both the severity of mobility restrictions imposed by governments to contain the pandemic and in the level of digital preparedness.

29. The crucial role of mobility restrictions in catalysing advertised telework and the importance of digital preparedness in mediating it is confirmed by econometric analyses. A tightening of government restrictions (and a decrease in mobility more generally) increases the share of advertised telework across countries. But the easing of restrictions leads to a decline only in countries with low levels of digital preparedness, whereas it has no effect in better prepared countries. Estimates from sector-level analyses confirm that digital preparedness plays a key role in mediating the response of advertised telework to government restrictions.

30. Overall, these results suggest that telework is here to stay, especially in digitally better prepared countries and sectors. Figure 8 uses the estimated model to predict the level of telework in a scenario where restrictions are completely lifted by end-2022. Even under this very optimistic scenario, advertised telework is predicted to roughly stabilise at about $7.5 \%$ of all job postings, on average, in countries with a high level of digital preparedness, while it is expected to slightly decrease to about $6 \%$ of all postings in countries with low levels of digital preparedness. ${ }^{13}$

31. Given that telework is likely here to stay, public policies need to make the most of its potential productivity and welfare-enhancing effects. In countries where telework has increased significantly and businesses currently post a significant share of teleworkable job ads, public policies need to focus on ensuring that workers are provided with an appropriate working environment (e.g. ICT equipment, office space and childcare); facilitating the diffusion of best practice managerial practices (e.g. shift from presenteeism to output-oriented assessment of worker productivity); and ensuring that there are no blind spots in terms of access to a fast, reliable and secure IT infrastructure (e.g. in rural areas, low-income workers) (OECD, 2020). In March 2020, for instance, Italy adopted a decree that facilitated "smart" working arrangements (including telework) under the condition that employers provide the necessary IT tools and share information with employees about the potential health and safety risks arising from these working arrangements.

32. In countries where telework has so far only caught on marginally, such as Japan or Israel, public policies should focus on encouraging telework since raising it from very low levels is likely to boost productivity and worker well-being (Behrens, Kichko, \& Thisse, 2021; Barrero, Bloom, \& Davis, 2021; OECD, 2020) and reduce commuting-related emissions, which would help meeting decarbonisation targets. This may involve strengthening key enabling factors, such as digital infrastructure and management skills, as well as catalysing telework by encouraging firms to grant workers the right to telework a minimum number of days per week. In May 2021, for instance, the metropolitan government of Tokyo introduced a subsidy for businesses if at least $70 \%$ of their staff work from home three days a week for three months.

\footnotetext{
${ }^{13}$ The in-sample fit of the model is shown in Annex Figure A.6.
} 
Figure 8. Advertised telework is predicted to stay substantially above its pre-pandemic level

Predicted trends in a scenario in which restrictions are gradually eased by end-2022

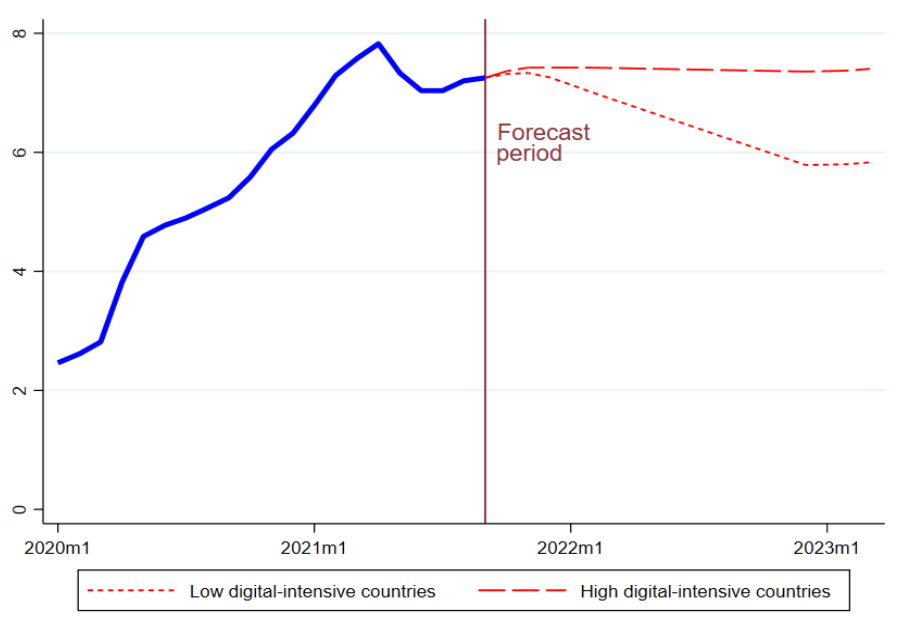

Note: The figure shows the predicted level of advertised telework in countries with a high and a low level of digital preparedness, as measured by broadband internet penetration, in a scenario in which government restrictions are gradually eased from their September 2021 levels over the rest of the year 2021 and the year 2022. Predicted levels are calculated using the coefficients reported in Figure 6, and starting from the actual cross-country average level of telework in September 2021. Long-term coefficients are obtained as the simple mean of the coefficients estimated for the $t+3, t+4$ and $t+5$ horizons. Countries with low (high) internet penetration are defined as those in which the number of per capita broadband subscriptions is below (above) the sample median.

Source: OECD calculations based on data from Indeed, Hale et al. (2021) and the OECD Broadband Portal. 


\section{References}

Adrjan, P. (2020), Searches for Remote Work Surge as Social Distancing Takes Hold. Retrieved from Indeed Hiring Lab: https://www.hiringlab.org/uk/blog/2020/03/23/searches-surge-remote-work/

Adrjan, P. (2021), The Office is Not Dead: Most Remote Job Postings Describe Remote Work as 'Temporary', Retrieved from Indeed Hiring Lab: https://www.hiringlab.org/uk/blog/2021/03/10/theoffice-is-not-dead/

Adrjan, P., \& Lydon, R. (2019), Clicks and jobs: measuring labour market tightness using online data, No. $6 / E L / 19$, Central Bank of Ireland.

Auerbach, A. J., \& Gorodnichenko, Y. (2012), Measuring the output responses to fiscal policy. American Economic Journal: Economic Policy, 4(2), 1-27.

Baldwin, R., \& Forslid, R. (2020), Globotics and Development: When Manufacturing is Jobless and Services are Tradable, National Bureau of Economic Research, Cambridge, MA.

Barrero, J., Bloom, N., \& Davis, S. (2021), Why Working from Home Will Stick. National Bureau of Economic Research, Cambridge, MA.

Behrens, K., Kichko, S., \& Thisse, J.-F. (2021), Working from Home: Too Much of a Good Thing? Retrieved from SSRN: https://papers.ssrn.com/sol3/papers.cfm?abstract id=3768910\#

Bloom, N. (2020), How working from home works out. SIEPR.

Chen, W. (2020), Disparities in Real Time, IMF Finance \& Development.

Criscuolo, C., Gal, P., Leidecker, T., Losma, F., \& Nicoletti, G. (2021), The role of telework for productivity and well-being during and post-COVID-19, OECD.

Dingel, J., \& Neiman, B. (2020), How Many Jobs Can be Done at Home? Journal of Public Economics, 189, 104235

Ens, E., Savoie-Chabot, L., See, K., \& Wee, S. L. (2021), Assessing Labour Market Slack for Monetary Policy, No. 2021-15, Bank of Canada.

Hale, T., Angrist, N., Goldszmidt, R., Kira, B., Petherick, A., Phillips, T., Webster, S., Cameron-Blake, E., Hallas, L., Majumdar, S. \& Tatlow, H. (2021), A global panel database of pandemic policies (Oxford COVID-19 Government Response Tracker), Nature Human Behaviour, 5(4), 529-538.

Jordà, Ò. (2005), "Estimation and inference of impulse responses by local projections", American Economic Review, 95(1), 161-182.

Judes, A. (2021), La France distancée sur le télétravail, qui marque le pas au premier trimestre 2021, Retrieved from Indeed Hiring Lab: https://www.hiringlab.org/fr/blog/2021/04/08/la-france-distanceesur-le-teletravail//

Ker, D., Montagnier, P., Spiezia V. (2021), Measuring telework in the COVID-19 pandemic. OECD Digital Economy Papers, No. 314, OECD Publishing, Paris

Kennedy, J. (2021), UK Employment Figures, June 2021: Labour Market Recovery Continues. Retrieved from Indeed Hiring Lab: www.hiringlab.org/uk/blog/2021/07/15/uk-employment-figures-june-2021/

Kolko, J. (2021), Remote Job Postings Double During Coronavirus and Keep Rising, Retrieved from 
Indeed Hiring Lab: https://www.hiringlab.org/2021/03/16/remote-job-postings-double/

OECD (2020), Productivity gains from teleworking in the post COVID-19 era: How can public policies make it happen? Retrieved from https://www.oecd.org/coronavirus/policy-responses/productivitygains-from-teleworking-in-the-post-covid-19-era-a5d52e99/

OECD (2021a), OECD Employment Outlook 2021: Navigating the COVID-19 Crisis and Recovery, OECD Publishing, Paris.

OECD (2021b), OECD Skills Outlook.

Rajan, R., \& Zingales, L. (1998), "Financial development and growth", American Economic Review, 88(3), 559-586.

Ramey, V. A., \& Zubairy, S. (2018), Government spending multipliers in good times and in bad: evidence from US historical data, Journal of Political Economy, 126(2), 850-901.

Romer, C. D., \& Romer, D. H. (2017), New evidence on the aftermath of financial crises in advanced countries, American Economic Review, 107(10), 3072-3118.

Taneja, S., Mizen, P., \& Bloom, N. (2021). Working from home is revolutionising the UK labour market. Retrieved from https://voxeu.org/article/working-home-revolutionising-uk-labour-market

Teulings, C. N., \& Zubanov, N. (2014), Is economic recovery a myth? Robust estimation of impulse responses, Journal of Applied Econometrics, 29(3), 497-514. 


\section{Annex A. Additional tables and figures}

Table A.1. Indeed job categories

\begin{tabular}{|c|c|c|}
\hline Accounting & Installation \& Maintenance & Sales \\
\hline Administrative Assistance & Insurance & Cleaning \& Sanitation \\
\hline Agriculture \& Forestry & Legal & Scientific Research \& Development \\
\hline Architecture & Management & Community \& Social Service \\
\hline Arts \& Entertainment & Production \& Manufacturing & Social Science \\
\hline Aviation & Marketing & Sports \\
\hline Personal Care \& Home Health & Mathematics & IT Operations \& Helpdesk \\
\hline Childcare & Dental & Information Design \& Documentation \\
\hline Construction & Physicians \& Surgeons & Software Development \\
\hline Customer Service & Media \& Communications & Therapy \\
\hline Driving & Medical Information & Logistic Support \\
\hline Education \& Instruction & Nursing & Veterinary \\
\hline Chemical Engineering & Medical Technician & Loading \& Stocking \\
\hline Civil Engineering & Military & \\
\hline Electrical Engineering & Mining & \\
\hline Industrial Engineering & Beauty \& Wellness & \\
\hline Mechanical Engineering & Pharmacy & \\
\hline Banking \& Finance & Project Management & \\
\hline Food Preparation \& Service & Security \& Public Safety & \\
\hline Hospitality \& Tourism & Real Estate & \\
\hline Human Resources & Retail & \\
\hline
\end{tabular}

Source: Indeed. 
Table A.2. List of keywords indicating advertised telework

\begin{tabular}{|c|c|c|c|}
\hline $\begin{array}{l}\text { Keywords for location } \\
\text { (country-specific) }\end{array}$ & Country & \multicolumn{2}{|c|}{$\begin{array}{l}\text { Keywords for description } \\
\text { (all countries) }\end{array}$} \\
\hline "Home Office" & AT & \multirow{22}{*}{$\begin{array}{l}\text { "Telearbeit" } \\
\text { "Heimarbeit" } \\
\text { "home office" } \\
\text { "homeoffice" } \\
\text { "home-office" } \\
\text { "mobiles office" } \\
\text { "mobiles arbeiten" } \\
\text { "von zu hause arbeiten" } \\
\text { "von zuhause arbeiten" } \\
\text { "arbeiten von zuhause" } \\
\text { "von zuhause aus" } \\
\text { "work remotely" } \\
\text { "work from home" } \\
\text { "working remotely" } \\
\text { "working from home" } \\
\text { remote work teleworking" } \\
\text { "remote work" } \\
\text { "teleworking" } \\
\text { "telework" } \\
\text { "telecommute" } \\
\text { "telecommute" } \\
\text { "telecommuting" } \\
\text { "work at home" } \\
\text { "remote" } \\
\text { "trabajo a distancia" } \\
\text { "trabajo remoto" } \\
\text { "teletrabajo" } \\
\text { "trabajo desde casa" } \\
\text { "teletreball" } \\
\text { "trabajar desde casa" } \\
\text { "teletrabajar" } \\
\text { "teletrabaja" } \\
\text { "tele-trabajar" } \\
\text { "en remoto" } \\
\text { "télétravail" } \\
\text { "travail à distance" } \\
\text { "travail à la maison" } \\
\text { "de la maison" } \\
\text { "telelavoro" } \\
\end{array}$} & \multirow{22}{*}{$\begin{array}{l}\text { "lavoro a distanza" } \\
\text { "lavoro in remoto" } \\
\text { "lavoro da remoto" } \\
\text { "lavoro da casa" } \\
\text { "lavorare remotamente" } \\
\text { "lavorare da remoto" } \\
\text { "da remoto" } \\
\text { "smart working" } \\
\text { "smartworking" } \\
\text { "テレワーク" } \\
\text { "在宅ワーク" } \\
\text { "内職" } \\
\text { "自宅での勤務" } \\
\text { "在宅型ワーク" } \\
\text { "自宅から 勤務" } \\
\text { "thuiswerken" } \\
\text { "Werken vanuit huis" } \\
\text { "zdalna" } \\
\text { "w domu" } \\
\text { "z domu" } \\
\text { "telepraca" } \\
\text { "praca zdalna" } \\
\text { "trabalho remoto" } \\
\text { "10o\% remoto" } \\
\text { "trabalho de casa" } \\
\text { "Teletrabalho" } \\
\text { "Trabalhar remotamente" } \\
\text { "arbeta på distans" } \\
\text { "arbeta hemifrån" } \\
\text { "arbete på distans" } \\
\text { "arbete hemifrån" } \\
\text { "distansarbete" } \\
\text { "Jobb på distans" } \\
\text { "Distansjobb" } \\
\text { "Jobba på distans" } \\
\text { "Jobba hemifrån" } \\
\text { "Jobb på distans" } \\
\text { "Jobb hemifrån" } \\
\text { "Distansjobb" } \\
\text { "Arbeta på avstånd" } \\
\end{array}$} \\
\hline "Werk van thuis" & $\mathrm{BE}$ & & \\
\hline "Remoto" & $\mathrm{BR}$ & & \\
\hline "Télétravail" & FR & & \\
\hline "Home Office" & $\mathrm{DE}$ & & \\
\hline "Lavoro da casa" & IT & & \\
\hline "Remote" & IE & & \\
\hline "Télétravail" & LU & & \\
\hline "Werk van thuis" & $\mathrm{NL}$ & & \\
\hline "En remoto" & ES & & \\
\hline "Home Based" & GB & & \\
\hline "Home Office" & $\mathrm{CH}$ & & \\
\hline "Remote" & US & & \\
\hline "Remote" & $\mathrm{CA}$ & & \\
\hline "Remote" & $A U$ & & \\
\hline "Remote" & NZ & & \\
\hline "Remote" & SG & & \\
\hline "Remote" & IN & & \\
\hline "Remote" & HK & & \\
\hline "zdalnie" & PL & & \\
\hline "Desde casa" & $M X$ & & \\
\hline "Jobba hemifrån" & SE & & \\
\hline
\end{tabular}

Source: Indeed 
Figure A.1. Job postings have held up better in sectors with low advertised telework in 2019

Change in job postings relative to January 2020 , average country, seasonally adjusted, $\%$

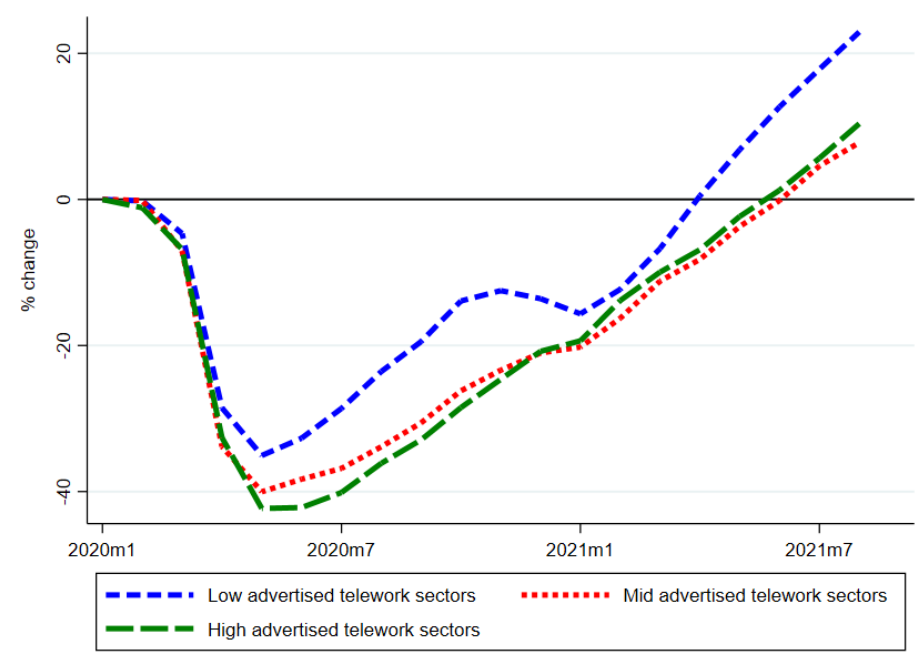

Note: Low, mid and high advertised telework sectors are those in the low, medium and high terciles of the sectoral distribution of the actual advertisement of telework before the Covid-19 pandemic, based on Indeed data.

Source: Indeed and OECD calculations.

Figure A.2. COVID-19 fatalities and government restrictions have similar but independent effects

Effects of government restrictions and per capita COVID-19 fatalities on advertised telework, estimated jointly
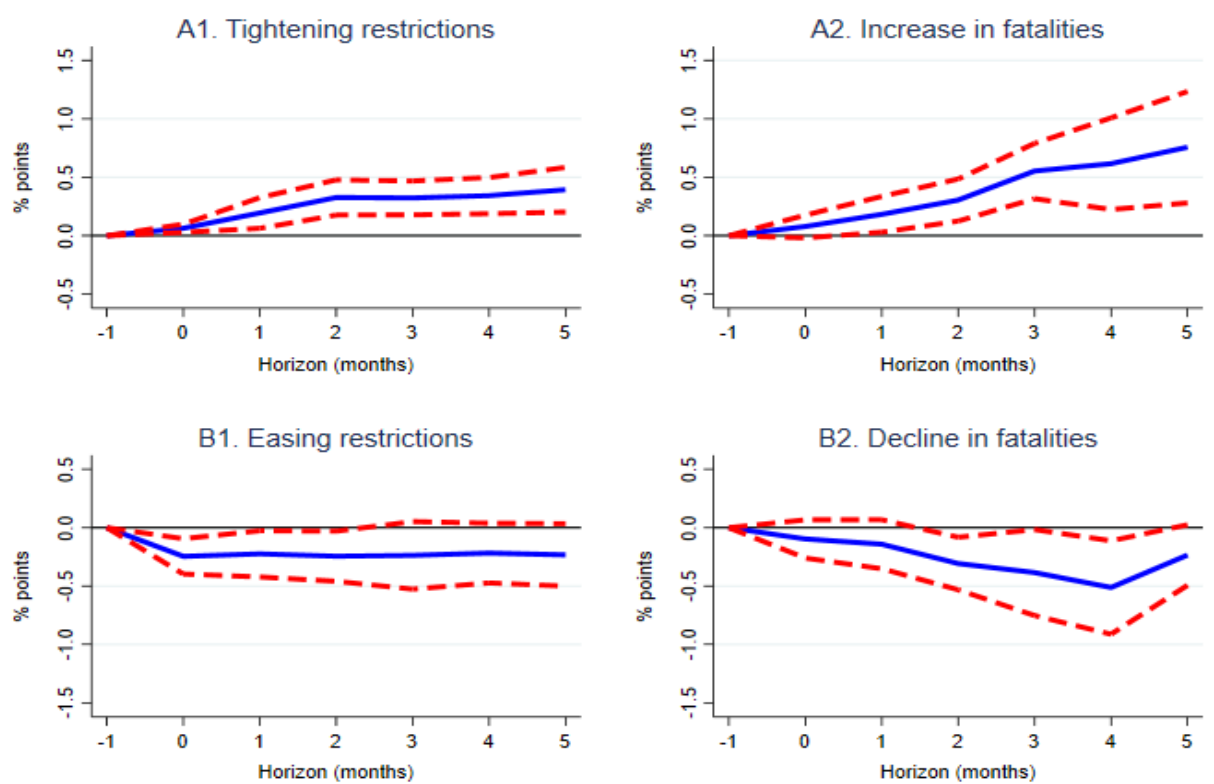

Note: The figure shows the cumulative effect of a 1 standard deviation positive and negative change in (i) the government restrictions index (respectively equal to about 15 points) and (ii) the incidence of COVID-19 fatalities (respectively equal to 8 fatalities per 100,000 inhabitants) on the share of job postings advertising telework, over a 6-month period. Blue solid lines denote point estimates, while red dashed lines are $90 \%$ confidence bands. Refer to Box 1 for details on the econometric methodology.

Source: Indeed, Hale et al. (2021) and OECD calculations. 
Figure A.3. Decreases in mobility are associated with a sharp rise in advertised telework

Effects of changes in people visits to shops, restaurants and other entertainment venues on advertised telework
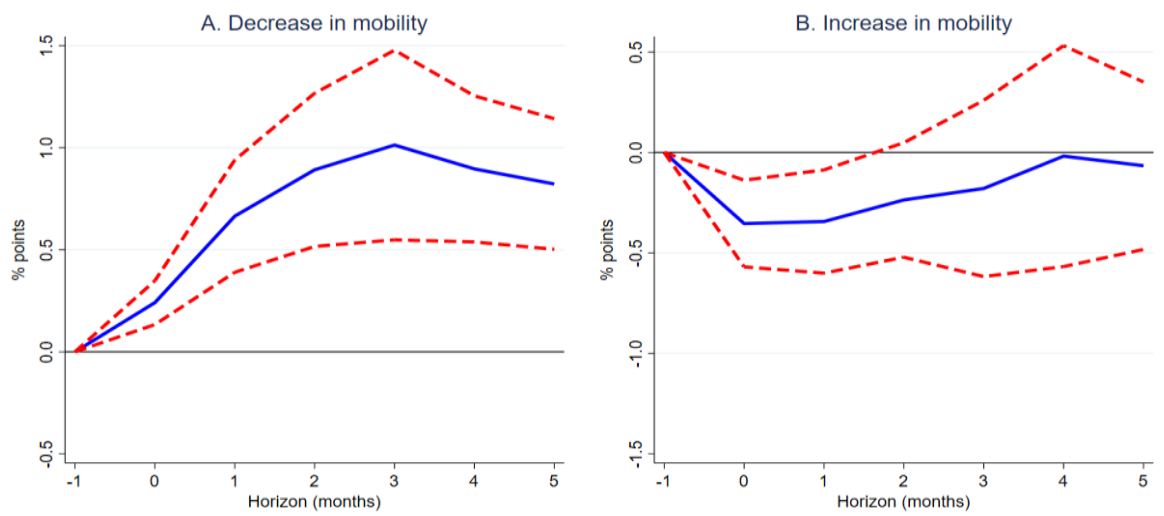

Note: The figure shows the cumulative effect of a 1 standard deviation positive and negative change in the frequency of people visits to shops, restaurants and other entertainment venues on the share of job postings advertising telework, over a 6-month period. Blue solid lines denote point estimates, while red dashed lines are $90 \%$ confidence bands. Refer to Box 1 for details on the econometric methodology.

Source: OECD calculations based on data from Indeed and Google COVID-19 Community Mobility Reports.

Figure A.4. The different effect of restrictions in low and high digitally prepared countries is robust

Effect of changes in government restrictions in countries with high and low levels of digital preparedness controlling for other country characteristics
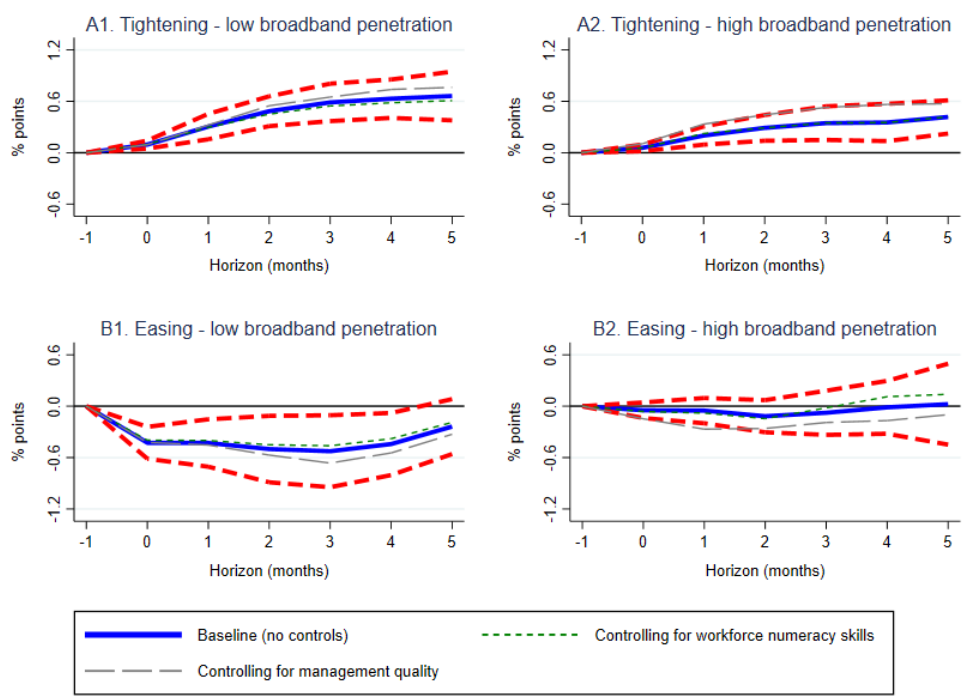

Note: The figure shows the cumulative effect of positive and negative changes in the government restrictions index on the share of job postings advertising telework, over a 6-month period, in countries with a low and a high level of digital preparedness, controling for the workforce's average numeracy skills and management quality. The charts report baseline estimates an confidence bands (not controlling for other factors, as in Figure 6 in the main text, thick blue solid and red dashed lines respectively), those obtained when controling for average numeracy skills (short-dashed green lines) and those obtained when controlling for management quality (long-dashed gray lines). Digital preparedness is measured as broadband internet penetration. Countries with low (high) preparedness are defined as those in which the number of per capita broadband subscriptions is below (above) the sample median. Refer to Box 1 for details on the econometric methodology.

Source: OECD calculations based on data from Indeed, OEC Broadband Portal, World Management Survey Portal and Hale et al. (2021) 
Figure A.5. Advertised telework followed similar trends across sectors before the pandemic

Share of advertised telework by sectors with different level of digital preparedness, average country, \%

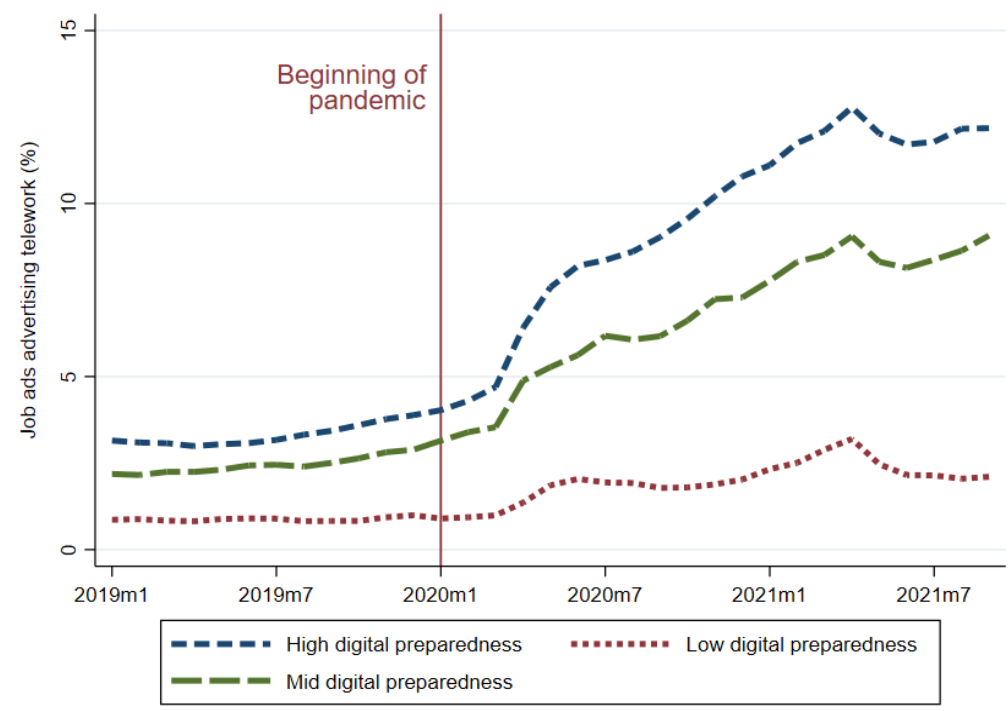

Note: The figure reports advertised telework in the average sector of the three groups of sectors with low, mid and high digital preparedness, which is measured as the share of jobs that can be carried out digitally, which is in turn based on the classification of Dingel \& Neiman (2020). Sectors are divided in the three groups based on whether they belong to the lower, middle or upper tercile of the distribution of the digital preparedness variable.

Source: Indeed, OECD calculations based on data from Dingel \& Neiman (2020).

Figure A.6. In-sample forecasts of advertised telework has a good fit

Actual and forecasted value of advertised telework, country average

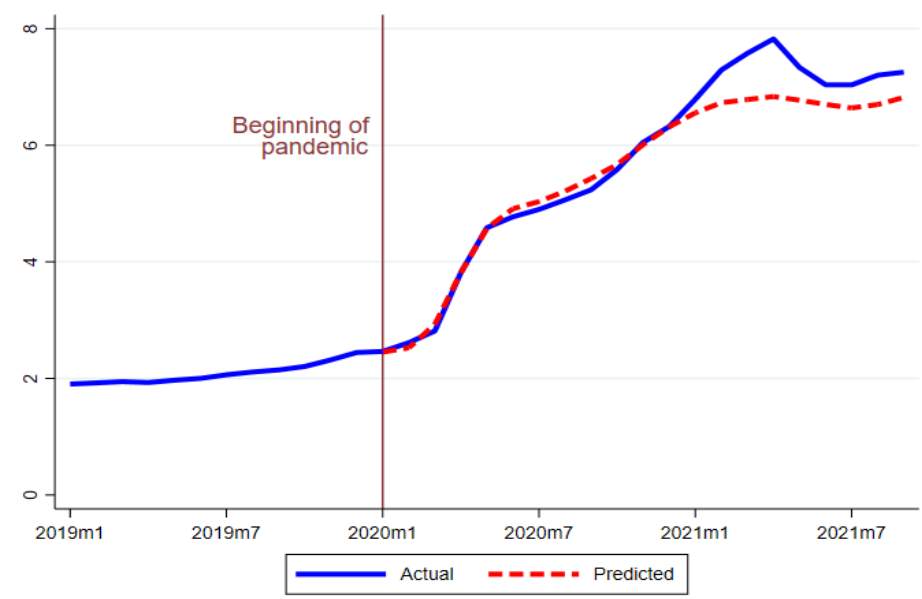

Note: The figure reports the cross-country average share of advertised telework and the one that would be predicted starting from the actual level of telework in January 2020 and using actual realizations of the government stringency index and the coefficients reported in Figure 6 to predict their effect on advertised telework. Long-term coefficients are obtained as the simple mean of the coefficients estimated for the $t+3, t+4$ and $t+5$ horizons.

Source: OECD calculations based on data from Indeed and Hale et al. (2021). 


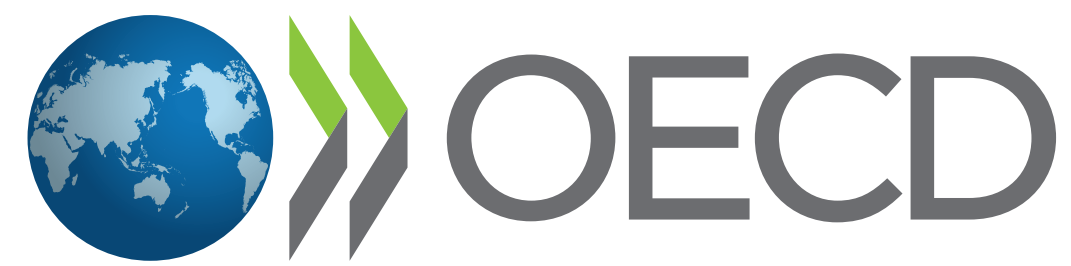

BETTER POLICIES FOR BETTER LIVES 